\title{
Transcriptional regulation of pyruvate kinase and phosphoenolpyruvate carboxykinase in the adductor muscle of the oyster Crassostrea gigas during prolonged hypoxia
}

\author{
Gilles Le Moullac ${ }^{*}$, Hélène Bacca ${ }^{2}$, Arnaud Huvet ${ }^{2}$, Jeanne Moal $^{2}$, \\ Stéphane Pouvreau ${ }^{1}$, Alain Van Wormhoudt ${ }^{3}$. \\ ${ }^{1}$ UMR 100 Physiologie et Ecophysiologie des Mollusques Marins, IFREMER, Site Expérimental d'Argenton, \\ Presqu'île du Vivier, 29840 Argenton en Landunvez, France. \\ 2 UMR 100 Physiologie et Ecophysiologie des Mollusques Marins, IFREMER, Centre de Brest, BP 70, 29280 \\ Plouzané, France. \\ ${ }^{3}$ UMR 5178 Biologie des Organismes et des Ecosystèmes Marins, Station de Biologie Marine du Muséum \\ National d'Histoire Naturelle, BP 225, 29900 Concarneau, France. \\ ${ }^{*}$ corresponding author (new address): \\ Gilles Le Moullac \\ IFREMER, Laboratoire Domestication de l'Huître Perlière, \\ BP 7004 \\ 98719 Afaahiti \\ Tahiti \\ Polynésie Française \\ Phone 00689506070 \\ Fax 00689506000 \\ Gilles.Le.Moullac@ifremer.fr
}

\begin{abstract}
:
The response of Crassostrea gigas to prolonged hypoxia was investigated for the first time by analyzing the metabolic branch point formed by pyruvate kinase (PK) and hosphoenolpyruvate carboxykinase (PEPCK). PK and PEPCK CDNAs were cloned and sequenced. The main functional domains of the PK sequence, such as the binding sites for ADP/ATP and phosphoenolpyruvate (PEP), were identified whereas the PEPCK sequence showed the specific domain to bind PEP in addition to the kinase-1 and kinase-2 motifs to bind guanosine triphosphate (GTP) and Mg2+, specific for all PEPCKs. A C-terminal extension was detected for the first time in eukaryota PK. Separation of mitochondrial and cytosolic fraction showed that more than 92\% of the PEPCK enzyme activity was cytosolic in gills, digestive gland, mantle and muscle. PK and PEPCK mRNAs and enzyme activities have been measured in muscle during prolonged hypoxia for 20 days. Adaptation of PK in hypoxic muscle at transcriptional level occurred lately by decreasing significantly the PK mRNA level at day 20 while PK enzyme activity was inhibited by the high content of alanine. The PEPCK mRNA ratio in hypoxic muscle significantly increased at day 10 simultaneously to the PEPCK enzyme activity. Succinate accumulation observed at day 10 and day 20 confirmed the anaerobic pathway of muscle metabolism in oyster subjected to hypoxia. Regulation of C. gigas PEPCK in muscle occurred at gene transcription level while PK was first regulated at enzyme level with alanine as allosteric inhibitor, and then at molecular level under a fast effect of hypoxia. J. Exp. Zool. 307A:371-382, 2007. (c) 2007 Wiley-Liss, Inc.
\end{abstract}

Keywords: Oyster, hypoxia, pyruvate kinase, phosphoenolpyruvate carboxykinase, alanine, succinate. 


\section{Introduction}

Marine molluscs can experience oxygen limitations during emersion in the intertidal zone and during hypoxic periods near the sediment or due to algal blooming. However, most marine molluscs tolerate low oxygen levels. In bivalves, this tolerance is first based on a mechanism of water pumping/ventilation (Tran et al., '00) which makes more oxygen available to the gills and improves its distribution to the tissues, helping to maintain the rate of oxygen consumption. This mechanism remains functional until an oxygen threshold is reached below which bivalves can no longer maintain a sufficient rate of oxygen consumption. This threshold, around $2 \mathrm{mg} \mathrm{O}_{2} \mathrm{~L}^{-1}$, defines the hypoxic threshold (Bricker et al., '99). The reduction of feeding activity and oxygen consumption is a frequently observed response to hypoxia in bivalves (Sobral and Widdows, '97, Chen, '98, Hicks and McMahon, '02).

Hypoxia and anoxia bring about a metabolic depression due to switching from aerobic to anaerobic less efficient energy production (Shick et al., '86, De Zwann et al, '91). This metabolic switch affects the final step of the glycolysis at the level of phosphoenolpyruvate (PEP). In aerobic mode, PEP is the substrate of pyruvate kinase $(P K)$ for the production of pyruvate. Pyruvate, a substrate of the Krebs cycle, is linked to ATP production via the respiratory mitochondrial chain. PEP can also be the substrate of gluconeogenesis which is essentially rate limited by phosphoenolpyruvate carboxykinase (PEPCK) (Schein et al., '04). The metabolic switch is controlled by several mechanisms such as the phosphorylation of PK (Simpfendörfer and al, '97, Greenway and Storey, '99), and the level of alanine leads to a reduction in its activity. When this occurs, PEP becomes mainly a substrate for PEPCK leading to the formation of succinate. If the response to hypoxia and anoxia in aquatic invertebrates has been widely studied, there is a lack of information on hypoxia tolerance of $C$. gigas at the physiological and molecular levels. Recently the response of $C$. gigas to hypoxia has been investigated focusing on the analysis of the differential expression pattern of specific genes associated showing regulations of energy metabolism but without detecting change of PK and PEPCK gene expression (David et al., '05). The cellular origin (cytosolic versus mitochondrial) of PEPCK allows to reveal some functional differences between cytosolic PEPCK (PEPCK-C) and mitochondrial PEPCK (PEPCK-M). Indeed, the activity of PEPCK-M and the turnover rate of mRNA appear to be constitutive (Weldon et al, '90, Hanson and Reshef, '97, Modaressi et al., '98) contrary to PEPCK-C.

This study was designed to determine the regulation level of the metabolic pathways in the adductor muscle of the oyster Crassostrea gigas by (1) describing the sequence of $C$. gigas PK and PEPCK CDNAs, (2) localizing the origin of PEPCK enzyme activity (mitochondrial versus cytosolic) and (3) analysing the mRNA levels and enzymatic activities of PK and PEPCK in muscle during a 20 day hypoxia. Succinate and alanine were quantified to validate the anaerobic pathway associated with the stimulation of PEPCK. 


\section{Material and methods}

\section{Biological material}

Sixteen months old oysters bred in the Ifremer experimental hatchery in Argenton (Finistère, France) were grown on in Aber Wrach (Finistère, France). Samples of oysters (individual weight $17.82 \pm 2.03$ grams) were collected at this site in October 2005 and placed in 300-L experimental tanks with $20 \mu \mathrm{m}$-filtered running seawater at the Ifremer laboratory in Argenton. The oysters were first adapted for one week to laboratory temperature (which was progressively increased up to $15^{\circ} \mathrm{C}$ ) and fed with an algal diet composed of Isochrysis at saturation level corresponding to a daily ration of $12 \%$ dry weight algae/dry weight oyster.

\section{Prolonged hypoxia}

Oysters were kept in same open flow tanks as above. Hypoxia was permanently maintained for 20 days and compared to normoxia. Normoxic oysters were kept in tank supplied continuously with oxygen saturated seawater at around $8.53 \mathrm{mg} \mathrm{O}_{2} \mathrm{~L}^{-1}$ and fed with an algal diet composed of Isochrysis supplied continuously at the concentration of $123 \pm 2610^{3}$ cell $\mathrm{mL}^{-1}$. Hypoxic oysters were maintained in hypoxic seawater and fed with the same diet at $130 \pm 2710^{3}$ cell mL $\mathrm{mL}^{-1}$. Hypoxia was obtained by bubbling nitrogen through oxygen saturated seawater of the continuous renewal which allowed the oxygen level to be reduced to $1.96 \mathrm{mg} \mathrm{O}_{2} \mathrm{~L}^{-1}$. To avoid the retaken of oxygen in the seawater, floating PVC plates are put on the water surface. For gene expression and enzyme activity measurements, the muscle of oysters were dissected, frozen immediately, pooled by 6 and stored in liquid nitrogen at days 0,2 , 10 and 20 after the beginning of the experimental conditioning. Tissue samples for gene expression and enzyme assay were frozen in nitrogen liquid, powdered with a Dangoumeau grinder and stored in liquid nitrogen. After each sampling, water renewal and algae distribution were adjusted to keep same environmental conditions.

\section{Ecophysiological measurements}

Measurement of clearance and oxygen consumption rates of the oyster populations subjected to normoxia and hypoxia, was carried out in tanks containing oysters and in control tank without animals. Each tank was connected to a system that provided continuous measurement of dissolved oxygen and chlorophyll level (Blain et al, '04). Values of these parameters were recorded every $2 \mathrm{~h} 30 \mathrm{~min}$ and allowed for the evaluation of oxygen consumption and ingestion rates of the oyster population in each tank. Taking into account the number of oysters, the ingestion rate (IR) and respiration rate (RR) were respectively expressed in cell $\mathrm{h}^{-1}$ ind $^{-1}$ and $\mathrm{mg} \mathrm{O}_{2} \mathrm{~h}^{-1}$ ind $^{-1}$ $\mathrm{IR}=[($ Chl. control - Chl. oyster $) \times \mathrm{FR}] / \mathrm{N}$

$\mathrm{RR}=\left[\left(\mathrm{O}_{2}\right.\right.$ control $-\mathrm{O}_{2}$ oyster $\left.) \times \mathrm{FR}\right] / \mathrm{N}$.

Where Chl. was the chlorophyll concentration $\left(F F U L^{-1}\right), \mathrm{O}_{2}\left(\mathrm{mg} \mathrm{O}_{2} \mathrm{~L}^{-1}\right)$ was the oxygen concentration, FR was the flow rate for sea water renewal $\left(\mathrm{L} \mathrm{h}^{-1}\right)$, and $\mathrm{N}$ was the number of oysters.

\section{Total RNA extraction and cDNA synthesis}

Total RNA was isolated using Extract-all reagent (Eurobio) at a concentration of 1

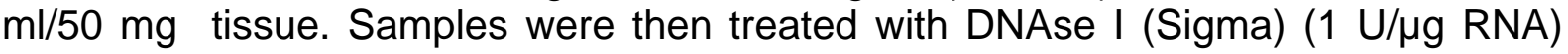
and precipitated by sodium acetate (3M, pH 5.2) treatment followed by washing with absolute ethanol. RNA concentrations were measured at $260 \mathrm{~nm}$ using the conversion factor: $1 \mathrm{OD}=40 \mu \mathrm{g} / \mathrm{ml}$ RNA. 
The polyadenylated RNA of samples were reverse-transcribed from $1 \mu \mathrm{g}$ of total RNA denatured for 10 minutes at $70^{\circ} \mathrm{C}$. Reactions were carried out in a total volume of 25 $\mu \mathrm{l}$ with the following concentrations of the reaction components: 1x M-MLV Reverse Transcriptase buffer, $0.2 \mathrm{mM}$ dNTPs, $4 \mathrm{mM}$ DTT, $0.5 \mu \mathrm{g}$ oligo(dT) primer, $25 \mathrm{U}$ ribonuclease inhibitor and $50 \cup \mathrm{M}-\mathrm{MLV}$ Reverse Transcriptase. Reverse transcription (RT) was carried out for $10 \mathrm{~min}$ at $25^{\circ} \mathrm{C}, 20 \mathrm{~min}$ at $42^{\circ} \mathrm{C}$ and then $5 \mathrm{~min}$ at $94^{\circ} \mathrm{C}$.

\section{PK and PEPCK cDNA cloning}

For PK cloning, a cDNA library was first constructed in lambda-ZAP II from C. gigas hemocytes mRNA. A consensus sequence was then obtained by amplification with two primers deduced by alignment of known PK sequences (Hui7 ${ }^{518} 5^{\prime}$ GAY CAN AAR GGN CCN GAR AR 3' ${ }^{550}$ and Hui8R ${ }^{1117} 5^{\prime}$ TGN GCN AGR AAN ACY TTY TC $3^{\prime}{ }^{1091}$ ). This consensus was 590bp in length. The $5^{\prime}$ end was obtained with the primer Huil $\left({ }^{894} 5^{\prime}\right.$ ACA TGA TTT TCG CGT CCT TC $3^{\prime}{ }^{914}$ ), selected inside the PCR fragment, and with the universal primer T7 present in the Bluescript cloning system of the lambda phage. The $3^{\prime}$ end was obtained in parallel using Huirev $\left({ }^{1057} 5^{\prime}\right.$ ACC ATG ATA CCA TCC GAC TCC T $3^{\prime}{ }^{1035}$ ) and T3 primers. Two fragments were obtained, 1400bp and 1200bp long. The sequences were read on an ABIPrism 410 sequencer (Applied Biosystems), and two other primers (Hui3 ${ }^{1415} 5^{\prime}$ GTC GCC ATA GCA GCA GTG GA $3^{\prime} 1435$ and Hui9r ${ }^{397} 5^{\prime}$ CCT TCA ATC ACC ATC TTC TGT $3^{\prime}{ }^{376}$ ) were used to complete sequencing.

For PEPCK cloning, a consensus fragment was obtained using two primers, cons5 $\left({ }^{1393} 5^{\prime}\right.$ TGG GAR GAY CCN AAR GGN GT $\left.3^{\prime}{ }^{1413}\right)$ and cons 4 r $\left({ }^{1686} 5^{\prime}\right.$ CGG AAC CAR TTN ACR TGR AA $3^{\prime}{ }^{1666}$ ), on a mantle lambda ZAP II library (Lelong et al., '00). The 3' end of PEPCK was obtained by PCR using nested primers (pepH1-M13 ${ }^{1489}{ }^{5}$ ' CAT GGC GTC ATG GTT GGA GC $3{ }^{\prime}{ }^{1509}$ and pepFW-T7 ${ }^{1504} 5^{\prime}$ GGA GCC TGC GTC AAA TCT GA $3^{\prime}{ }^{1524}$ ). The $5^{\prime}$ end of PEPCK was obtained by RACE PCR (Boehringer Mannheim). Two successive PCR were realised with two oligonucleotide, first pepH4r-dT anchor $\left({ }^{1496} 5^{\prime}\right.$ CGC CAT GTT GCC AGC TGT AG 3' ${ }^{1476}$ ), and then pepH10r-anchor ( ${ }^{1181} 5^{\prime}$ GCA TGG CAT TGG GGT TAG TT $3^{\prime 1161}$ ) on total mRNA extracted from the mantle. The 750bp fragment obtained was then sequenced and was truncated. This allowed to design a new primer pair (PepH13r-anchor ${ }^{568} 5^{\prime}$ ACT GAA GGG GAT CAC ATA CA $3^{\prime}{ }^{548}$ ) and the PCR amplification of the 500 bp 5' end. Two other primers: pepH11R ${ }^{1259} 5^{\prime}$ CCT CCA TTC CCT CCC AGA A $3^{\prime}{ }^{1240}$ and pepH ${ }^{1918} 5^{\prime}$ TTC CTG GAG GAC CAG GTC GG $3^{\prime}{ }^{1938}$ were used for final sequencing.

\section{PK and PEPCK mRNA expression}

For spatial localization of PK and PEPCK in gills, digestive gland, gonad, mantle and muscle, the levels of glycolytic gene transcripts were investigated (table 1) by realtime PCR using an Icycler (Bio-Rad) using actin as internal control for gene expression (as in Huvet et al., '04). No significant differences between Ct values were observed for the actin gene between gill, mantle, digestive gland, gonad and muscle $(\mathrm{P}=0.36)$.

For the hypoxia experiment, actin was substituted for Elongation factor I (EF1) as internal control (Fabioux et al , '04) to analyse PK and PEPCK gene transcription. No significant differences between $\mathrm{Ct}$ values were observed for the two house keeping genes actin $(P=0.34)$ and EF1 $(P=0.95)$ between normoxia and hypoxia. The coefficient of variation was $4.3 \%$ and $3.3 \%$ for actin and elongation factor $\mathrm{I}$. Therefore, the relative quantification value of the sample was normalized to the EF1 gene (because of its lower $P$ value and coefficient of variation). 
The specific primers were synthesized as follows : (PK) PKHui1, 5'ACATGATTTTCGCCTCCTTC-3'; PKHui2R, 5'-TCTCTGgGgGAATCTCAATG-3'; (PEPCK) PEPCKPEPH1, 5'-CATGGCGTCATGGTTGGAGC-3', PEPCKPEPH2R, 5'GTCAAGCCAGTGCTGTAGG-3'. The real-time PCR assay was performed in triplicate with $5 \mu \mathrm{L}$ cDNA (1/5 dilution) in a total volume of $15 \mu \mathrm{L}$. The concentrations of the reaction components were $0.33 \mu \mathrm{M}$ of each primer and 1x iQ SYBR Green Supermix (Biorad). This reaction was performed as follows: activation at $95^{\circ} \mathrm{C}$ for $5 \mathrm{~min}$ followed by 45 cycles of $30 \mathrm{sec}$ at $95^{\circ} \mathrm{C}, 1 \mathrm{~min}$ at $60^{\circ} \mathrm{C}$, and a melting curve program from $95^{\circ} \mathrm{C}$ to $70^{\circ} \mathrm{C}$ that decreased the temperature by $0.5^{\circ} \mathrm{C}$ every 10 seconds. Each run included a positive cDNA control (one sample of the experimental mixture analyzed per amplification plate), negative controls (replicates of each total RNA sample without reverse transcriptase) and blank controls (water) for each primer pair. PCR efficiency (E) was determined by drawing standard curves from a serial dilution analysis of cDNA from samples to ensure that E ranged from 99 to 100\% for each primer pair. The fluorescence threshold value was calculated using the Icycle iQ system software. Relative expression was normalized using Actin to investigate glycolytic genes in tissues and EF1 to investigate the effect of hypoxia in adductor muscle as controls: $\mathrm{QR}=2^{-\left(\mathrm{Ct} t_{\text {target }}-\mathrm{Ct}_{\text {reference }}\right)}$.

\section{Tissular localization of PK and PEPCK and PEPCK cellular localization}

At reception in the laboratory, spatial distribution for gene expression and enzyme activity measurements of PK and PEPCK were done using 12 oysters which were dissected to collect 5 tissues (gills, digestive gland, gonad, mantle and muscle). Tissue samples for gene expression and enzyme assay were frozen in nitrogen liquid, powdered with a Dangoumeau grinder and stored in liquid nitrogen.

Cellular localization of PEPCK was analysed on four tissues (muscle, digestive gland, gills and mantle) of $C$. gigas. After dissection the tissues were pooled and then homogenized by Potter in ice cold buffer $(1 \mathrm{~g} w \mathrm{w} / 4 \mathrm{~mL})(10 \mathrm{mM}$ Tris $\mathrm{pH} 7.2,5 \mathrm{mM}$ EDTA, and $250 \mathrm{mM}$ sucrose). The homogenate was centrifuged at $900 \times \mathrm{g}$ for $10 \mathrm{~min}$ $\left(4^{\circ} \mathrm{C}\right)$ and the resultant supernatant was centrifuged at $10000 \times \mathrm{g}$ for $15 \mathrm{~min}\left(4^{\circ} \mathrm{C}\right)$. Cytosolic fraction (supernatant) was then centrifuged at $100000 \times \mathrm{g}$ for $60 \mathrm{~min}\left(4^{\circ} \mathrm{C}\right)$. Mitochondrial fraction was centrifuged three times at $10000 \times \mathrm{g}$ for $10 \mathrm{~min}\left(4^{\circ} \mathrm{C}\right)$. The pellet was resuspended in $2 \mathrm{~mL}$ buffer, sonicated and centrifuged at $18000 \times \mathrm{g}$ for 20 $\min \left(4^{\circ} \mathrm{C}\right)$. PEPCK enzyme activity was assessed as described below. Cytochrome $\mathrm{C}$ oxidase (Sigma CYTOCOX1-1KT) was used as markers to control a possiblel crosscontamination between the two fractions.

\section{Enzyme extraction and assay}

Powdered frozen tissues were used for enzyme assay. Using a 1:5 w/v ratio for all tissues, the aliquots were homogenized in a buffer composed of $50 \mathrm{mM}$ imidazole$\mathrm{HCl}$ buffer ( $\mathrm{pH}$ 7.2), $100 \mathrm{mM} \mathrm{Na} 3 \mathrm{~F}, 5 \mathrm{mM}$ EDTA, $5 \mathrm{mM}$ EGTA and $15 \mathrm{mM} 2-$ mercaptoethanol. A few crystals of phenylmethylsulfonyl (PMSF) were added immediately prior to homogenization. The homogenates were centrifuged for 20 min at $20000 \mathrm{~g}$ at $5^{\circ} \mathrm{C}$. Blanks were run and subtracted. Changes in $\mathrm{NAD}(\mathrm{P}) \mathrm{H}$ absorbance at $340 \mathrm{~nm}$ were monitored using a Biotek Microplate Reader. Assays were conducted at $30^{\circ} \mathrm{C}$ and initiated by mixing the $230 \mu$ reagent preparation, with the homogenate $(20 \mu \mathrm{L})$. The preparation for Pyruvate kinase (PK; EC 2.7.1.40) was as follows: $100 \mathrm{mM}$ imidazole-HCl buffer ( $\mathrm{pH} 7.2), 50 \mathrm{mM} \mathrm{KCl}, 5 \mathrm{mM} \mathrm{MgCl}, 10 \mathrm{mM}$ phosphoenol pyruvate, $2 \mathrm{mM}$ ADP, $0.15 \mathrm{mM} \mathrm{NADH}, 0.2 \% 2(\mathrm{v} / \mathrm{v})$ rotenone-saturated ethanol, and $1 \mathrm{U} / \mathrm{ml} \mathrm{LDH}$. For Phosphoenolpyruvate carboxykinase (PEPCK; EC 4.1.1.32) the preparation was: $100 \mathrm{mM}$ imidazole- $\mathrm{HCl}$ buffer ( $\mathrm{pH} \mathrm{6.6),} 30 \mathrm{mM} 2-$ 
mercaptoethanol, $5 \mathrm{mM}$ phosphoenolpyruvate, $50 \mathrm{mM} \mathrm{NaHCO}_{3}, 1.25 \mathrm{mM}$ IDP, $1 \mathrm{mM}$ $\mathrm{MnCl}_{2}, 0.15 \mathrm{mM} \mathrm{NADH}$, and $2.5 \mathrm{U} / \mathrm{ml} \mathrm{MDH}$.

\section{Alanine and succinate determination}

Metabolites were extracted from $200 \mathrm{mg}$ of the oyster powder prepared as described above with $2 \mathrm{ml}$ of trichloro-acetic acid (TCA), neutralized with $1.2 \mathrm{ml}$ of amine freon trioctylamine/trifluoro-trichloro-ethane, v:v, 1:5). Alanine was measured enzymatically according to standard procedures as described by Williamson ('74). Succinate was quantified with the succinate determination kit of R-Biopharm Inc (Marshall, MI, USA).

\section{Kinetics and statistics}

Kinetic properties of PK enzyme were defined as Greenway and Storey ('00). The substrate affinity constant $\left(\mathrm{S}_{0.5}\right)$ is defined as the concentration of substrate at which the enzyme the enzyme reaction proceeds at $50 \%$ of its maximal velocity. $S_{0.5}$ is defined by fitting data from the double reciprocal plots (Lineweaver-Burk plot) of rate versus substrate (PEP) concentration. $I_{50}$ is defined as the concentration of inhibitor (alanine) required to reduce enzymes activity to half its value in the absence of inhibitor. $I_{50}$ values were obtained from the Dixon plots of rate versus inhibitor concentration.

Data are given as means \pm SE of oyster pools in normoxic and hypoxic group at each time point. A one-way ANOVA followed by Fisher's test was used to determine if individual time point means differed from time 0 means within each oxygen level group. T-tests were utilized to determine if there were differences between means of normoxic and hypoxic group at each time point. Differences were considered significant at $P<0.05$. Statistical analyses were performed using Statview (SAS). 


\section{Results}

\section{Molecular characterization of phosphoenolpyruvate carboxykinase and pyruvate kinase}

The nucleotide sequence of $C$. gigas PEPCK (AM 076952) was 2561 bp long. The deduced sequence of amino acids (fig 1a) compared with databases by using the Blast algorithm showed very high similarity with other PEPCK proteins. Comparison by multiple alignments indicated 53-63.4\% identity between the PEPCKs of different vertebrate and invertebrate species (fig 1a). The putative deduced mature sequence encoded a 615 amino acid protein of $69.25 \mathrm{kDa}$ molecular weight. The potential ATG codon initiator was present at nucleotide 193-195 from the 5' position of the PEPCK nucleotide sequence. The functional domains of the PEPCK identified on the sequence obtained from $C$ gigas were highly conserved. The oxaloacetate binding site, as well as the kinase- 1 and kinase-2 motifs for binding GTP and $\mathrm{Mg}^{2+}$ respectively were common to all PEPCKs (Matte et al., '97).

The total PK sequence isolated (AM 076953) was 2121 bp long. The deduced sequence of amino acids (fig. 1b) showed very high similarity with other PK proteins and encoded a 563 amino acid pre-protein of $61.345 \mathrm{kDa}$ molecular weight. Comparison by multiple alignments indicated $58.6-65.7 \%$ identity between the PKs from different species of vertebrates and invertebrates (fig $1 \mathrm{~b}$ ) and showed that it is a M-type PK. The main functional domains of the sequence were identified. The ADPIATP binding site was a highly conserved sequence of 389 to 420 residues $\left({ }^{389}\right.$ TRAESSDVANAVLDGADCVMLSGETAKGDYPLEC $\left.{ }^{420}\right)$. The PEP binding site was composed of amino acids located at different positions in the sequence (Munoz and Ponce, '03). These residues were Arg-117, Asp-157, Lys-317, Glu-319, Ala-340, Arg341, Gln-376, Ser-409 and Glu-411 (fig 1b). The region involved in the formation of the binding site for fructose 1- 6 biphosphate $(\mathrm{F} 1,6 \mathrm{BP})$ included 16 residues which were observed in the $C$. gigas sequence ${ }^{471}$ MAAAIIVITTSGRSAH ${ }^{486}$. A C-terminal extension was present that did not correspond to a functional motif as it is the case in bacteria.

\section{Tissue localization of PK and PEPCK and cellular localization of PEPCK}

The level of PK activity was tissue-dependant (table 1). The level of relative mRNA and enzyme activity was significantly different between the tissues $(P<0.1 \%)$. PLSD Fisher test allowed to classify the tissues according to the mean level of PK activity (table 1). This table indicates that the PK activity was the highest in the muscle and the lowest in the mantle and the gills. The PEPCK activity was significantly different between the tissues $(P<0.1 \%)$. The activity of the PEPCK was the highest in the muscle and the lowest in the digestive gland, the mantle and the gills (table 1). PEPCK enzyme activity was mainly detected in cytosol representing 96\%, 92\%, 99\% and $94 \%$ of the total PEPCK activity respectively in gills, digestive gland, mantle and muscle (table 1).

\section{Response to prolonged hypoxia}

Hypoxia induced a significant depression of respiration and ingestion, since RR was significantly reduced $(\mathrm{P}<5 \%)$ by $83 \%$ from $0.60 \pm 0.03$ to $0.11 \pm 0.06 \mathrm{mg} \mathrm{O}_{2} \mathrm{~h}^{-1}$ ind $^{-1}$, and IR decreased by $55 \%$, from $48.4410^{3} \pm 4.65$ to $26.6510^{3} \pm 5.05 \mathrm{cell} \mathrm{h}^{-1}$ ind $^{-1}$. The results are given as means $\pm S E(n=16)$. 
The PK mRNA ratio in hypoxic muscle decreased during the experimental period, the change of PK mRNA ratio became significant at day 20 compared to day 0 (fig $2 a$ ). Differences with normoxia were significant at day 10 and day 20. Inversely, the activity of PK enzyme did not change in hypoxic muscle, while the PK activity in normoxic muscle increased significantly at day 10 and day 20 compared to day 0 . The PK activity in normoxic muscle was significantly higher from hypoxic muscle at day 10 and day 20 (fig 2b). The PEPCK mRNA ratio in hypoxic muscle significantly increased only at day 10 compared to day 0 and at day 10 was significantly higher than PEPCK mRNA ratio of normoxic muscle (fig 2c). Significant differences in PEPCK activity were observed at day 10 between normoxic and hypoxic conditions (fig 2d).

Alanine content in normoxic muscle decreased significantly at day 10 and day 20 compared to day 0 (fig. 3a). In hypoxic muscle, the level of alanine remained high and unchanged. The level of alanine in normoxic and hypoxic muscle became significantly different at day 10 and day 20 (fig. 3a). Succinate level in hypoxic muscle increased significantly at day 20 . The succinate content was significantly higher than at day 0 and higher than in normoxic muscle (fig $3 b$ ).

Hypoxia exposure led to significant change in the kinetic properties of PK enzyme activity in muscle. The PEP affinity constant $\left(S_{0,5}\right)$ was strongly reduced by six fold (table 2). PK enzyme activity from hypoxic muscle also showed much greater inhibition by L-alanine, with the $I_{50}$ value reduced to only $14 \%$ of the corresponding normoxic value. 


\section{Discussion}

The high similarity between the PEPCK sequence from $C$. gigas and PEPCK from other invertebrates and vertebrates, combined with the conservation of the PEPCKspecific domain, suggests that the cloned enzyme is a functional form of PEPCK. The PEPCK protein occurs in two isozyme forms in vertebrates: a cytosolic form (PEPCK-C) and a form present in the matrix of the mitochondria (PEPCK-M). In the putative signal peptide of the $C$. gigas PEPCK sequence there are 3 successive (Glu, Asp, Asp) residues, which provide a key element for determining the origin of this sequence. This residue pattern rules out a mitochondrial origin according to Roise and Schatz ('88). Our result confirmed the cytosolic origin of the PEPCK since we detected $93 \%$ of the activity in the cytosol in all analysed tissues. This result contrast with crab muscle whose PEPCK enzyme activity is mainly detected in the mitochondrial fraction (Schein et al, '04). The cytosolic oyster PEPCK form may be therefore a non-constitutive form as shown in other organisms. Indeed functional differences between PEPCK-C and PEPCK-M exist. Enzyme activity is regulated by nutritional and hormonal stimuli at the transcription level for the PEPCK-C gene. In contrast, the activity of PEPCK-M and the turnover rate of mRNA appear to be constitutive (Weldon et al, '90, Hanson and Reshef, '97, Modaressi et al., '98). In trout, the PEPCK-M expressed at a high level in the liver and is not regulated by dietary carbohydrate (Panserat et al., 2001).

The amino acid sequence of $C$. gigas PK was compared to Human (R/L and M), to invertebrate such as Drosophila, Caenorhabditis and Bacillus PK's. Amino acid sequence alignment revealed that PK is highly conserved from the bacillus to the more highly evolved vertebrate mammalian. The expression of these genes is tissuespecific and under developmental, dietary and hormonal control. In vertebrate tissues, there are four PK isozymes coded by two genes ( $L$ and $M$ ): $R$ (in red blood cells), L (in liver), M1 (in skeletal muscle) and M2 (in kidney, adipose tissue and lung) (in Munoz and Pounce, '03) which are characterized by their kinetic properties. The PK isoenzymes are expressed in a tissue-specific manner reflecting the different metabolic requirements of the tissues (Imamura and Tanaka, '72). $L$ and M2 isoforms are allosterically regulated by fructose 1,6 biphosphate (F1,6BP) (Boles et al, ' 97 ). The $C$. gigas $\mathrm{PK}$ sequence contained a motif suggesting this type of regulation due to the presence of an Arg-402 residue. Ikeda et al ('97) converted the M1 isoenzyme of PK rat, a non allosteric isoenzyme, into an allosteric enzyme substituting Ala-398 with Arg. The spatial distribution of PK and PEPCK in $C$ gigas tissues showed that PK and PEPCK mRNA level were more elevated in muscle. This resulted in high enzymatic activities of PK and PEPCK in muscle as previously observed in $C$ virginica (Greenway and Storey, '99). The high level of PK enzymatic activity in the muscle would allow an intense glycolysis to quickly provide ATP for contractile activity. As fuel, glycogen in oyster muscle is low and reaches $5 \%$ of the total biochemical content (Berthelin et al., '00). This low storage capacity is related to a low glycogen synthase expression in muscle compared to gonad and palps (Bacca et al., '05). As muscle is not a storage tissue for glycogen, it needs to be supplied with glucose at high rate to maintain an aerobic pathway of energy production.

During hypoxia, the oysters present a metabolic depression expressed by a lower ingestion rate (45\%) and a lower oxygen consumption (82\%) than oysters maintained in normoxic conditions. This response is common to hypoxia tolerant organism (Sobral and Widdows, '97, Zhou et al, '00, Alexander and McMahon, '04) leading to a reduced energy metabolism and a shift to anaerobic metabolism. If the 
ecophysiogical behaviour of oysters was expected, our experiment showed contrasted results at cellular and molecular level. Long term hypoxia led to changes which affect the enzymes controlling the metabolic pathways. For PEPCK, our results showed in hypoxic muscle a late induction at day 10 of gene expression and enzyme activity followed by an accumulation of succinate. The late induction of PEPCK gene expression and enzyme activity with a succinate accumulation indicated the anaerobic alternate pathway of energy production setting (De Zwann et al., '83). Greenway and Storey ('99) observed also a 50\% increase of PEPCK enzyme activity in mantle of anoxic $C$. virginica only in winter. The anaerobic pathway in facultative anaerobic marine invertebrates is the conversion of PEP to oxaloacetate in the reaction catalysed by a GTP-dependent PEPCK. Metal ion availability, nucleotide or PEP levels and also alanine, ITP and $\mathrm{H}^{+}$concentration would be effectors to control PEPCK activity (Zammit and Newsholmes, '78). But in adductor muscle of Perumytilus purpuratus, PEPCK did not appeared to be regulated by intracellular modulators (Vial et al., '95). Change in PEPCK gene expression and enzyme activity appeared simultaneous in hypoxic muscle suggesting as Vial et al. ('95) that a regulation of PEPCK of $C$. gigas could occur, as for vertebrates (Pilkis et al, '88) at a level of gene transcription.

Hypoxia also involved the decrease of mRNA relative value of PK. This decrease was late and only observed from day 10 . At day 20 , the decrease of PK mRNA relative value was 2.5 times lower than at day 0 . PK enzyme activity remained weak and stable while in normoxia the PK enzyme activity increased significantly and was 2 times higher at day 10 compared to day 0 . These differences between the response of the PK enzyme and the PK mRNA value suggest different levels of regulation. Change in $\mathrm{PK}$ enzyme activity in muscle was understandable taking into account the alanine content. Initially at day 0 , alanine content in normoxic muscle was high (around $14 \mu \mathrm{M} \mathrm{g}^{-1} \mathrm{ww}^{-1}$ ). Over the experimental period, alanine in normoxic muscle decreased significantly contributing to release PK activity. In hypoxia, the level of alanine remained high and thus the PK activity in hypoxic muscle remained low. Moreover the kinetic properties of PK are modified by hypoxia showing a low affinity for PEP and a greater sensitivity to alanine. This adaptation provides a method for making stable yet reversible changes to enzyme properties, allowing them a short term response to oxygen level variations. The molecular basis of PK enzyme activity suppression in response to lack of oxygen are described in many species of marine molluscs (Storey, '93, Greenway and Storey, '00) consisting in covalent modification via phosphorylation mechanism. The phosphorylation of PK which occurs in hypoxic environment reduces its affinity for PEP, reduces sensitivity to the allosteric activator fructose-1,6-biphospahte (F1,6BP) and greatly increases enzyme inhibition by alanine from anaerobic metabolism (Plaxton and Storey, '84, Storey, '93).

The late decrease of PK mRNA and increased of PEPCK mRNA corresponded to the switch from the aerobic to the anaerobic metabolic pathway. This could be linked to the nutritional status since the oyster reduced their feeding in hypoxia and hence reduced the glycolytic flux. Our results suggested that the lack of oxygen such as a prolonged hypoxia at $2 \mathrm{mg} \mathrm{O}_{2} \mathrm{~L}^{-1}$ applied on C. gigas oyster would induce a fast. In vertebrate and invertebrate, fasting stimulates the production of alanine (Muller et al, '71, Okama and Abe, '98). This corroborates our results showing a high level of alanine in muscle of hypoxic oyster over the experimentation. In vertebrate, fasting acts also on PK and PEPCK by suppression of PK gene expression in rats (Decaux and Hemon, '90) and by induction of PEPCK gene expression (Lemaigre and Rousseau, '94). These regulations are linked to glucose that stimulate transcription of 
the PK-M gene (Yamada and Noguchi, '99), and inhibits PEPCK gene expression but also accelerates the PEPCK mRNA degradation (Meyer et al, '91).

The present study provides evidence about the adaptation mechanisms of $C$. gigas muscle to prolonged hypoxia, using PK and PEPCK as indicators of metabolic pathways. Their cDNA sequences were characterized which allowed their relative mRNA levels to be measured. Regulation level in muscle was determined by comparing relative mRNA level and enzyme activity. It appears that the effects of hypoxia are more complex at the tissue level than at the level of the whole organism. The present work showed in $C$. gigas muscle that the PEP branchpoint lately switched (at day 10) from the aerobic to the anaerobic pathway of energy production. This was shown by the induction of PEPCK enzyme activity leading to the succinate accumulation. The PK enzyme activity was controlled by alanine. Alanine was high at the beginning of the experiment certainly due to a low trophic condition before this experimentation. Then, over the experimentation, while the trophic level was high, the level of alanine decreased in normoxic oyster allowing to "release" PK enzyme from the alanine inhibition. But in hypoxia the level of alanine remained high, contributing to inhibit PK enzyme activity. The high level of alanine would be due to the fasting effect on hypoxic oyster. At molecular level, the decrease of PK mRNA and the increase of PEPCK mRNA in hypoxic muscle confirmed the switch of the PEP metabolic branchpoint that would be an effect of fasting. Lastly, this study suggested that PEPCK enzyme activity was regulated by the level of PEPCK mRNA, while PK enzyme activity was immediately regulated by allosteric effector such as alanine, before to be regulated at the transcriptional level.

\section{Acknowledgments}

This work was supported by the Morest national project funded by Ifremer, the Régions of Basse Normandie, Bretagne, Pays de Loire and Poitou-Charentes and the Conseil Général du Calvados. Our thanks to Jean-François Samain of the Morest Project and Michel Mathieu, Director of the UMR 100 Physiologie et Ecophysiologie des Mollusques Marins. Thanks also to Helen McCombie-Boudry for improving the English in this paper. 


\section{Literature cited}

Alexander JE, McMahon RF 2004. Respiratory response to temperature and hypoxia in the zebra mussel Dreissena polymorpha. Comp Biochem Physiol B, 137: 425434.

Bacca H, Huvet A, Fabioux C, Daniel JY, Delaporte M, Pouvreau S, Van Wormhoudt A. 2005. Molecular cloning and seasonal expression of oyster glycogen phosphorylase and glycogen synthase genes. Comp Biochem Physiol B 140: 635-646.

Berthelin C, Kellner K, Mathieu M. 2000. Storage metabolism in relation to summer mortalities and reproductive cycle (West Coast of France). Comp Biochem Physiol B 125: 359-369.

Blain S, Guillou J, Treguer P, Worther P, Delauney L, Follefant E, Gontier O, Hamon M, Leildé B, Masson A, Tartu C, VuilleminR. 2004. High frequency monitoring of the coastal marine environment using the MAREL buoy. J Environ Monit, $6: 569$ 575.

Boles E, Schulte F, Miosga T, Freidel K, Schülter E, Zimmermann FK. 1997. Characterization of a glucose repressed pyruvate kinase (Pyk2p) in Saccharomyces cerevisiae that is catalytically insensitive to fructose-1,6biphosphate. J Bacteriol 179: 2987-2993.

Bricker SB, Clement CG, Pirhalla DE, Orlando SP, Farrow DRG. 1999. National Estuarine Eutrophication Assessment. Effects of Nutrient Enrichment in the Nation's Estuaries NOAA, National Ocean Service, Special Projects Office and the National Centers for Coastal Ocean Science Silver Spring, MD, p 71.

Chen YL. 1998. The respiratory physiology and energy metabolism of freshwater mussels and their responses to lack of oxygen. Faculty of the Virginia Polytechnic Institute and State University. PhD dissertation, p 88.

David E, Tanguy A, Pichavant K, Moraga D. 2005. Response of the pacific oyster Crassostrea gigas to hypoxia exposure under experimental conditions. FEBS journal 272: 5635-5652.

Decaux JF, Antoine B, Kahn A, 1989. Regulation of the expression of the L-type pyruvate kinase gene in adult rat hepatocytes in primary culture. J Biol Chem 264: 11584-11590.

De Zwann A, de Bont AMT, Hemelraad J.1983. The role of phosphonenolpyruvate carboxykinase in the anaerobic metabolism of the sea mussel Mytilus edulis L. J Comp Physio 153: 267-274.

De Zwaan A, Cortesi P, van den Thillart G, Roos J, Storey KB. 1991. Differential sensitivies to hypoxia by two anoxia-tolerant marine molluscs: a biochemical analysis. Mar Biol 111: 34-351.

Greenway SC, Storey KB. 1999. The effect of prolonged anoxia on enzyme activities in oysters (Crassostrea virginica) at different seasons. J Exp Mar Biol Ecol 242: 259-272.

Greenway SC, Storey KB. 2000. Seasonal change and prolonged anoxia affect the kinetic properties of phosphofructokinase and pyruvate kinase in oysters. J Comp Physiol B 170: 285-293.

Hanson RW, Reshef L. 1997. Regulation of phosphoenolpyruvate carboxykinase (GTP) gene expression. Annu Rev Nutr 66:581. 
Hicks DW, McMahon RF. 2002. Respiratory responses to temperature and hypoxia in the nonindigenous Brown Mussel, Perna perna (Bivalvia: Mytilidae), from the Gulf of Mexico. J Exp Mar Biol Ecol 277:61-78.

Hochachka PW and. Lutz PL. 2001. Mecahnism, origin and evolution of anoxia tolerance in animals. Comp Biochem Physiol 130B: 435-459.

Huvet A, Herpin A, Dégremont L, Labreuche Y, Samain JF, Cunningham C. 2004. The identification of genes from the oyster Crassostrea gigas that are differentially expressed in progenies exhibiting opposed susceptibility to summer mortality. Gene 343:211-220.

Ikeda Y, Tanaka T, Noguchi T. 1997. Conversion of non allosteric pyruvate kinase into an allosteric enzyme by a single amino acid substitution. J Biol Chem 272: 20495-20501.

Imamura K, Tanaka T. 1972. Multimolecular forms of pyruvate kinase from rat and other mammalian tissues. I. Electrophoretic studies. J Biochem (Tokyo) 71: 1043.

Kahn A. 1997. Transcriptional regulation by glucose in the liver. Biochimie 79: 113118.

Keitzmann T, Schmidt H, Probst I, Jungermann K. 1992. Modulation of the glucagondependent activation of the phosphoeno/pyruvate-carboxykinase gene by oxygen in rat hepatocyte cultures. FEBS 311: 251-255.

Lemaigre FP, Rousseau GG. 1994. Transcriptional control of genes that regulate glycolysis and gluconeogenesis in adult liver. Biochem J 303: 1-14

Matte A, Tari LW, Goldie H, Delbaere LTJ. 1997. Structure and Mechanism of Phosphoenolpyruvate Carboxykinase. J Biol Chem 272: 8105-8108.

Meyer S, Höppner W, Seitz HJ. 1991. Transcriptional and post-transcriptional effects of glucose on liver phosphoeno/pyruvate-carboxykinase gene expression. Eur $\mathrm{J}$ Biochem 202: 985-991.

Modaressi S, Brechetl K, Crist B, Jungermann K. 1998. Human mitochondrial phosphoenolpyruvate carboxykinase 2 gene. Structure, chromosomal localization and tissue-specific expression. Biochem J 333: 359-366.

Müller WA, Faloona GR, Unger RH. 1971. The effect of alanine on glucagon secretion. J Clin Invest. 50: 2215-2218.

Munoz ME, Ponce E. 2003. Pyruvate kinase: current status of regulatory and functional properties. Comp Biochem Physiol 135B: 197-218.

Mustafa T, Hoachachka PW. 1971. Catalytic and regulatory properties of pyruvate kinases in organes of a marine bivalve. J Biol Chem 246: 3196-3203.

Okama E, Abe H. 1998. Effects of starvation and D- or L- alanine administration on the free D- and L- alanine levels in the muscle and hepatopancreas of the crayfish, Procambarus clarkii. Comp Biochem Physiol 120A: 681-686.

Panserat S, Plagnes-Juan E, Brèque J, Kaushik S. 2001. Hepatic phosphoenolpyruvate carboxynase gene expression is not repressed by dietary carbohydrates in rainbow trout (Onchorhynchus mykiss). J Exp Biol 204: 359-365.

Pilkis SJ, El Magrabi MR, Claus TH. 1988. Hormonal regulation of hepatic gluconeogenesis and glycolysis. Ann Rev Biochem 57: 755-783.

Plaxton WC, Storey KB. 1984. Purification and properties of aerobic and anoxic forms of pyruvate kinase from red muscle organ of the channeled whelk, Busycotypus canaliculatum. Eur J Biochem 143: 257-265.

Roise D, Schatz G. 1988. Mitochondrial presequences. J Biol Chem 263: 4509-4511.

Schein V, Waché Y, Etges R, Kucarcsky LC, Van Wormhoudt A, Da Silva RSM. 2004. Effect of hyperosmotic shock on phosphoenolpyruvate carboxykinase gene expression and glucogenic activity in the crab muscle. FEBS letters 561: 202-206. 
Shick JM, Gnaiger E, Widdows J, Bayne BL, de Zwann A. 1986. Activity and metabolism in the mussel Mytilus edulis L. during intertidal hypoxia and aerobic recovery. Physiol Zool 59: 627-642.

Simpfendörfer RW, Vial MV, Monjsalve A. 1997. The adductor muscle pyruvate kinase from the intertidal bivalve Mytilus chilensis (Hupé): evidence of the presence of phosphorylated form of the enzyme during the entire tidal cycle. $\mathrm{J}$ Exp Mar Biol Ecol 213: 169-179.

Sokolova IM, Pörtner HO. 2001. Temperature effects on key metabolic enzymes in Littorina saxatilis and $L$. obtusata from different latitudes and shore levels. Mar Biol 139: 113-126.

Storey KB. 1993. Molecular mechanism of metabolic arrest in molluscs. In: Hochachka PW, Lutz PL Sick T, Rosenthal M, van den Thillart G (eds) Surviving Hypoxia : Mechanisms of Control and Adaptation. CRC Press; Boca Raton: 253269.

Tran D, Boudou A, Massabuau JC. 2000. Mechanism for maintaining oxygen consumption under varying oxygenation levels in the freshwater clam Corbicula fluminea. Can J Zool 78: 2027-203.

Vial MV, Oelckers KB, Rojas MC, Simpfendörfer RW. 1995. Purification, partial kinetic characterization and reactive sulfhydryl groups of the phosphoenolpyruvate carboxykinase from Perumytilus purpuratus adductor muscle. Comp Biochem Physiol 112B: 451-460.

Weldon SL, Rando A, Matathias AS, Hod Y, Kalonick PA, Savon S, Cook JS, Hanson RW. 1990. Mitochondrial phosphoenolpyruvate carboxykinase from the chicken, comparison of the cDNA and protein sequences with the cytosolic isozyme. J Biol Chem 265: 7308-7317.

Yamada K, Noguchi T. 1999. Review Nutrient and hormonal regulation of pyruvate kinase gene expression. Biochem J 337: 1-11.

Zammit VA, Newholmes E. 1978. Properties pyruvate kinase and phosphoenolpyruvate carboxykinase in relation to the direction and regulation of phosphoenolpyruvate metabolism in muscles of the frog and marine invertebrates. Biochem. J.174: 979-987.

Zhou BS, Wu RSS, Randall DJ, Lam PKS, Ip YK, Chew SF. 2000. Metabolic adjustment in the common carp during prolonged hypoxia J Fish Biol 57: 11601171. 
Caenorhabditis Drosophila Homocyto Homomito Crassostrea Xenopus

Caenorhabditis Drosophila Homocyto Homomito Crassostrea Xenopus

MPELIEQSKI ISGNVCGLPQ LHKLRQDNCG LYSHIRGIPI SYGNVDLLTT GVRAFVEEGI ALCQPDQVHI CDGSEQENKV MPPQL QNGLNLSAKV VQGSLDSLPQ AVREFLENNA ELCQPDHIHI CFGSEEENGR -
-..--MPSFY VRAVGPCSRI VRGWVESQKT RCRGAHAVRV LSGQMERLPP AVREFVVKGA ELCDPQNIHI CDGSATENET

$$
\begin{array}{llllllll}
90 & 100 & 110 & 120 & 130 & 140 & 150 & 160
\end{array}
$$
$\ldots|\ldots| \ldots|\ldots| \ldots|\ldots| \ldots|\ldots| \ldots|\ldots| \ldots|\ldots| \ldots|\ldots| \ldots|\ldots| \ldots|\ldots| \ldots|\ldots|$ IVDKLVERGV LTPLKAYENN YLCRTDPRDV ARVESKTWMV TKDKYDSVCH TPDGVRPIMG QWMSEEQFGV ELDSRFPGCM LIKSLLEAGT IVPLPKYDNC WLARTNPADV ARVESRTFIC TERREETIPT PVEGVKGTLG NWISPSDMDA AVOORFPGCM LLGOMEEEGI LRRLKKYDNC WLALTDPRDV ARIESKTVIV TQEQRDTVPI PKTG-LSQLG RWMSEEDFEK AFNARFPGCM TLTLLEQQGL IRKLPKYNNC WLARTDPKDV ARVESKTVIV TPSQRDTVPL PPGGACGQLG NWMSPADFQR AVDERFPGCM VTHKLIERGV LTKLKKYENC YLCRTDPADV ARVESKTWIA TDDKYETVPH VRQGVRGILG QWKHTKEMEE EVNSDLDGCM IVTVLQQEGM LKKLHKYPNC WLARTDPKDV ARVESKTVIV TENMRDTVPI PTTGVKGQLG NWMSPQDFER AKAERFPGCM

Caenorhabditis Drosophila Homocyto Homomito Crassostrea Xenopus 
HUMAN_RL

DROSOPHILA

HUMAN_M

OYSTER

BACILLUS

CAENORHABDITIS

HUMAN RL

DROSOPHILA

HUMAN_M

OYSTER

BACILLUS

CAENORHABDITIS

HUMAN_RL

DROSOPHILA

HUMAN_M

OYSTER

BACILLUS

HUMAN RL

DROSOPHILA

HUMAN M

OYSTER

BACILLUS

CAENORHABDITIS

HUMAN_RL

DROSOPHILA

HUMAN M

OYSTER

BACILLUS

CAENORHABDITIS

HUMAN_RL

DROSOPHILA

HUMAN M

OYSTER

BACILLUS

CAENORHABDITIS

HUMAN_RL

DROSOPHILA

HUMAN_M

OYSTER

BACILLUS

CAENORHABDITIS

HUMAN_RL

DROSOPHILA

HUMAN_M

OYSTER

BACILLUS

CAENORHABDITIS

HUMAN RL

DROSOPHILA

HUMAN_M

OYSTER

BACILLUS

CAENORHABDITIS

HUMAN RL

DROSOPHILA

HUMAN_M

OYSTER

BACILLUS
CAENORHABDITIS

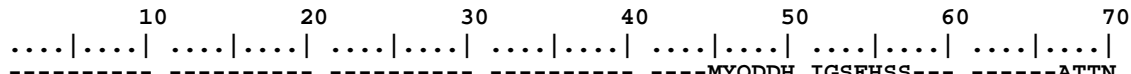
MSIQENISSL QLRSWVSKSQ RDLAKSILIG APGGPAGYLR RASVAQLTQE LGTAFFQ-QQ Q-PAAMADTF -

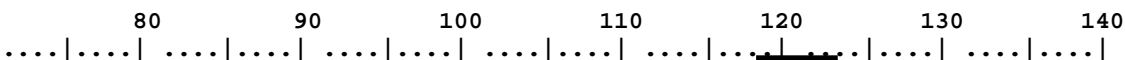
ISHLCGLRIS ERPQKTRKTG VICTIGPACS DVETLRKMIN TGMNIARLNF SH LEHLCLLDID SEPVAARSTS IIATIGPASR SVERLKEMIK AGMNIARLNF SHGSHEYHAE SIANVREAVE LEHMCRLOFD SPVPHVRLSG IVCTIGPASS SVEMLEKMMA TGMNIARMNF SHGSHEYHAA TVANVROAVK LEHMCRLDID SPPITARNTG IICTIGPASR SVETLKEMIK SGMNVARLNF SHSTHEYHAE TIKNVRTATE LLLMCKLDID SNPRDVSMTG IICTIVPACR EIDTLQKMVI EGMNVARLNF SHSTHEYHEG TIKNIREAVK

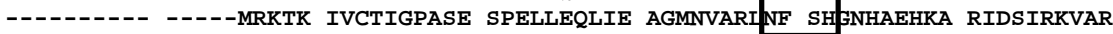

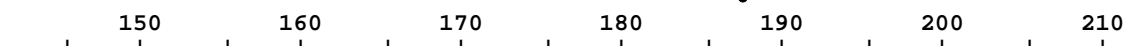

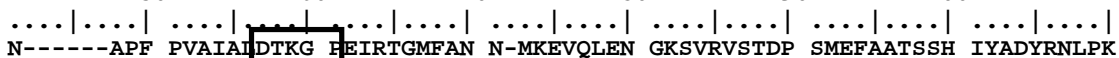
SFAGSPLSYR PVAIALDTKG PEIRTGILOG GPESEVELVK GSOVLVTVDP AFRTRGNANT VWVDYPNIVR NYSAKLGYEH PVAIALDTKG PEIRTGLIGG SGTAEIELKK GEKIKLTTNK EFLEKGSLEI VYVDYENIVN SFASDPILYR PVAVALDTKG PEIRTGLIKG SGTAEVELKK GATLKITLDN AYMEKCDENI LWLDYKNICK GFSSP - - - R PLAIALDTKG PEIRTGLLEG GASAELTLNT GDKIKITTDD KFKEKCSKDT LWVDYKNITK EKG -..---K VVGILLDTKG PEIRTHSMMN G---KLELVT GQKIDISMT- --QVEGNNDV FSVSYDKLIE

230

240

250

260

270

280

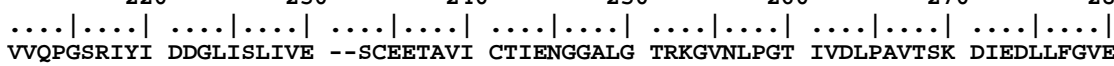
VVPVGGRIYI DDGLISLVVQ --KIGPEGLV TQVENGGVLG SRKGVNLPGA QVDLPGLSEQ DVRDLRFGVE VVKPGNRVFV NDGLISLIVR - -EVGKDSLT CEVENGGSLG SRKGVNLPGV PVDLPAVSEK DKSDLLFGVE VVEVGSKIYV DDGLISLQVK --QKGADFLV TEVENGGSLG SKKGVNLPGA AVDLPAVSEK DIQDLKFGVE VMSVGSRMFI DDGLISVIVK --EMGADYIN CVVENGGDLG SKKGCNLPGI AVDLPAVSTK DKEDLLFGVA DVNEGSVILL DDGLIQLEVT GKDVARGLIH TLIINSGSLS NNKGVNIPGV SVQLPGMTEK DAEDILFGIR

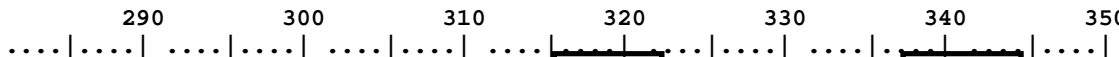
QGVDIIFASF IRNADGIHKI RQVLGEK-GK HIYI HGVDIVFASF VRKASDVAAV RAALGPE-GH GIKI] SKIEN HEGVKRFDEI LEVSDGIMVA RGDIGIEIPA QEVDMIFASF IRNAAALTEI RKVLGEK-GK NIKI] SKIEN QQGMHNLDEI IEAGDGIMVA RGDLGIEIPA ODVDMVFASF IRKASDVHEV RKVLGEK-GK NIKI SKIEN HEGVRRFDEI LEASDG IMVA RGDIGIEIPA QGVDMIFASF IRSGQHIKDI RSILGEK-GK NIKI AKIEN HEGVRFDEI LQESDG MVA RGDLGIEIPP EGVDFIAASF VRRASDVMEI RALLENNNGS NLQI PKIEN QEGVDIDEI LNVSDG MVA RGDIGVEIPP

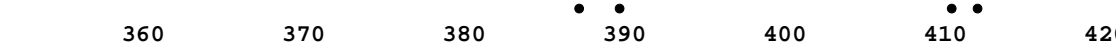

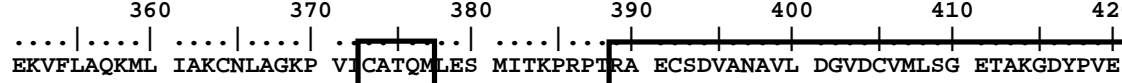
EKVFLAQKMM IGRCNLAGKP V CATQMLES MITKPRPTRA ETSDVANAVL DGADCIMLSG ETAKGNFPVE EKVFLAQKAM IARCNKAGKP V] CATQM LES MVKKPRPTRA EISDVANAVL DGADCVMLSG ETAKGEYPLE EKVFLAOKMM IGRCNRAGKP VI CATOMLES MIKKPRPTRA EGSDVANAVL DGADCIMLSG ETAKGDYPLE EKVFLAQKMM IGRCNRAGKP VICATQM ES MVKKPRPTRA ESSDVANAVL DGADCVMLSG ETAKGDYPLE EEVPLVQKNL IEKCNQAGKP VITATQNLSS MQRNPRPTRA EASDVANAIF DGTDAIMLSG ETAAGIYPVE$$
430 \quad \text { ADP/ATP } \bullet
$$

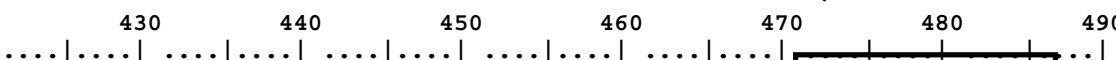
ALAIMHNICK EAESAFFHMK HFEELILHTK KPTGMTHTTA IAAVSATITC AVKMOHAIAR EAEAAVYHRO LFEELRRAAP LSRDPTEVTA IGAVEAAFKC CAAAIIVLTT TGRSAOLSR CVLTMAKTCK EAEAALWHQN FFNDLVRGAG -TIDASHAAA IAAVEAATKA KASAIVVITT SGKSAFpVSK

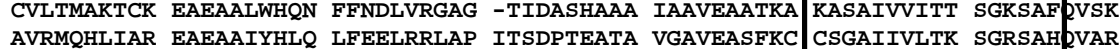
CVKMMQKICR EAESAVFHHQ LFEELRKETP TPTDATHTVA IAAVEASFKC SVQTMDRIAL TTEAAIDYRS VVSTRRREKH - -GNMTEAIG QAAAYTAINL KVKAVLAPTE SGHTAK IIAK

$$
\text { F1, } 6 \text { BP }
$$

$$
\begin{array}{llllll}
500 & 510 & 520 & 530 & 540 & 550
\end{array}
$$

$\ldots|\ldots| \ldots|\ldots| \ldots|\ldots| \ldots|\ldots| \ldots|\ldots| \ldots|\ldots| \ldots|\ldots| \ldots|\ldots| \ldots|\ldots| \ldots|\ldots|$ YRPPVPIITV SRDERISRQL HLHRGIFPVY YPKGRIDEWD VDVEERVQYG VNLGKTRGFI HLGDPLIVIT YRPRAAVIAV TRSAQAARQV HLCRGVFPLL YREPPEAIWA DDVDRRVQFG IESGKLRGFL RVGDLVIVVT YRPRCPIIAV TRFAQTARQA HLYRGLVPLI YKEPGLGDWL KDVDVRVQFG LQVGKKNGFI KTGDSVVVVT YRPRAPIIAV TRNPQTARQA HLYRGIFPVL CKDPVQEAWA EDVDLRVNFA MNVGKARGFF KKGDVVIVLT YRPRCPILAI TRIEOTAROC HLFRGIFPIH YVDSVMSEWT VDVDRRIYKG IOSGMDRGFI OKGDPVIIIT YRPGCPVIAV TSSEMCSRKL SLIWGVYPIV GKKAS--.-- -SIDEILQES VEESVKHQYV GHGDVVIITA

$\begin{array}{lllllll}570 & 580 & 590 & 600 & 610 & 620 & 630\end{array}$

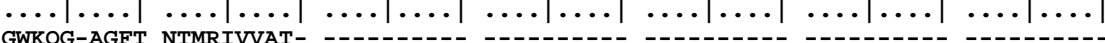
GWRPG-SGYT NIMRVLSIS- GWKQG-SGFT NTIRIVTVE-

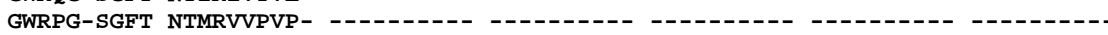
GWKPG-SGST NTMRIINAVD VANKDLLAPI TGITSVPSFD KIESDLSNRS SRTSLPDSTK GSKDDVKFFGVPVGEAGTT NLMKIHVIGD LLARGQGIGK DVAYGRTVVA KNAAEALAYD TEGAILVTNA SDRDMMPAIE

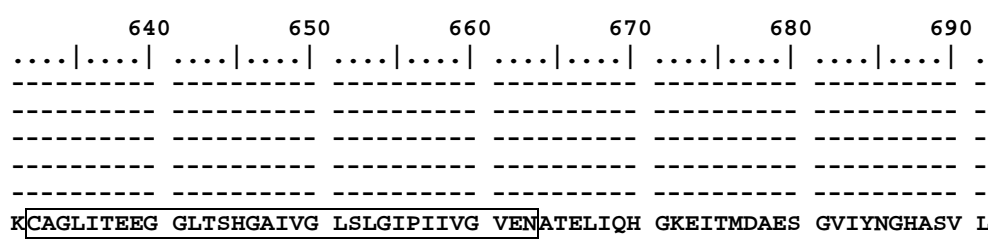

Fig. 1. Continued. 
a

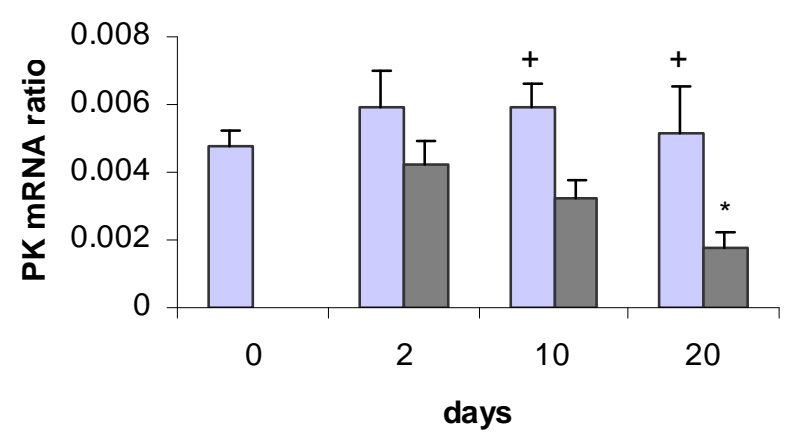

C

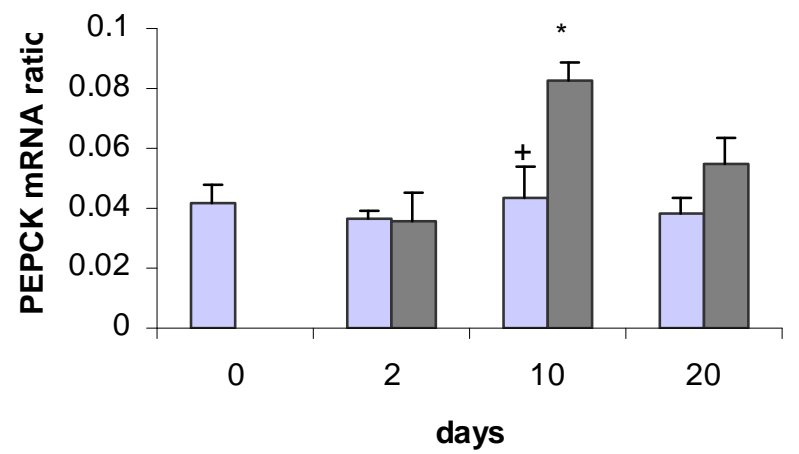

b

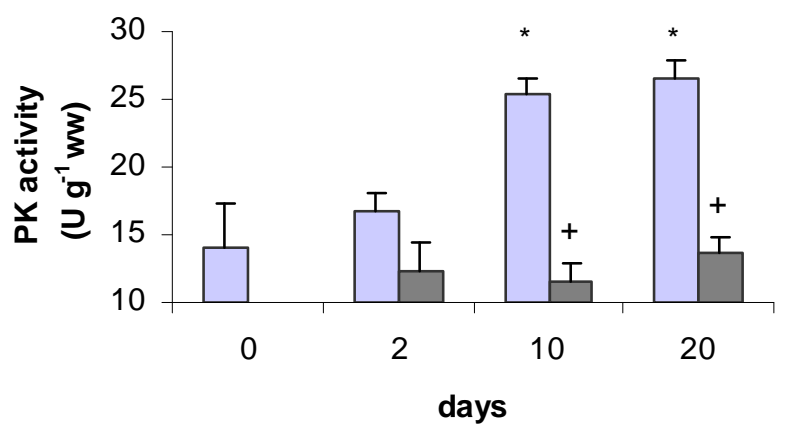

d

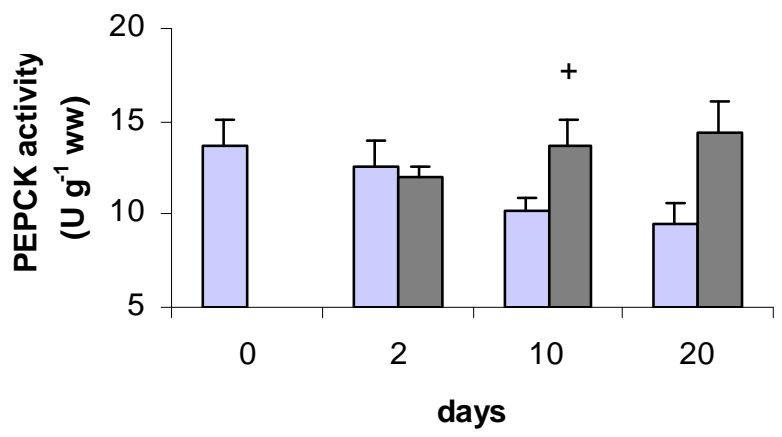

Figure 2: The effects of oxygen on PK and PEPCK mRNA ratio and enzyme activity in $C$. gigas muscle in normoxia (grey) and hypoxia (dark). PK mRNA ratio (a), PK activity (b), PEPCK mRNA (c) ratio and PEPCK activity (d). Results are means $\pm S E, n=6-8$. *, significant difference $(p<0.05)$ relative to day 0 within each group. + , significant difference $(p<0.05)$ between normoxia and hypoxia at each sampling day.

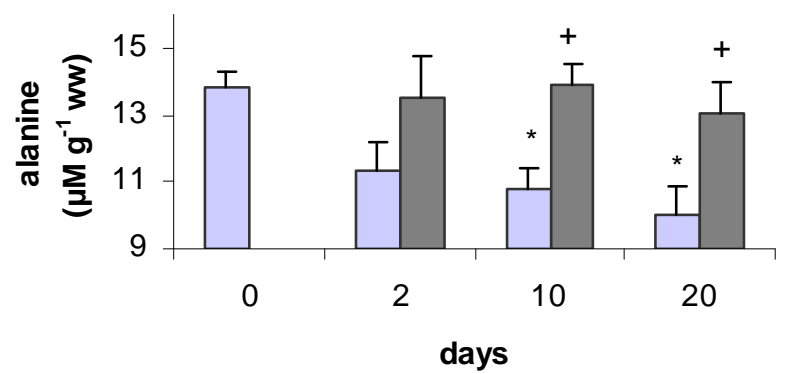

$\mathrm{b}$

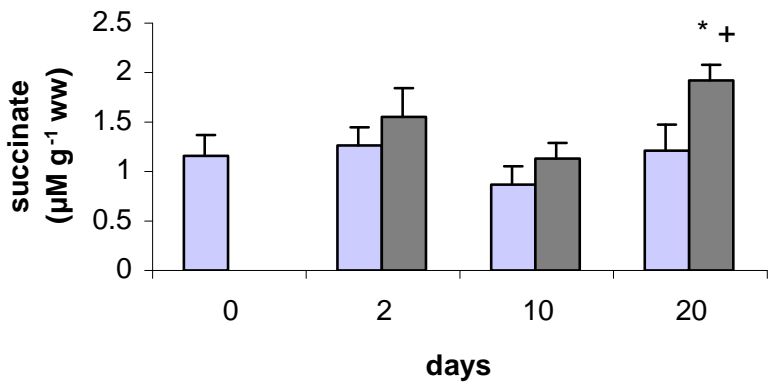

Figure 3: The effects of oxygen on alanine and succinate in C. gigas muscle in normoxia (grey) and hypoxia (dark). Alanine (a), Succinate (b). Results are means $\pm S E, n=6-8$. *, significant difference $(p<0.05)$ relative to day 0 within each group. + , significant difference $(P<0.05)$ between normoxia and hypoxia at sampling each day. 


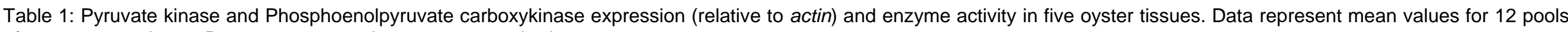
of 5 oysters per tissue. Data are expressed as mean \pm standard error.

\begin{tabular}{|c|c|c|c|c|c|c|}
\hline \multirow[b]{2}{*}{ Organ } & \multirow[b]{2}{*}{$\mathrm{n}$} & \multicolumn{2}{|c|}{ Pyruvate kinase } & \multicolumn{3}{|c|}{ Phosphoenolpyruvate kinase } \\
\hline & & $\begin{array}{l}\text { Gene expression } \\
\times 10^{-2}\end{array}$ & $\begin{array}{l}\text { Enzyme activity } \\
U^{-1} \text { WW }\end{array}$ & $\begin{array}{l}\text { Gene expression } \\
\times 10^{-2}\end{array}$ & $\begin{array}{l}\text { Enzyme activity } \\
\cup \mathrm{g}^{-1} \text { WW }\end{array}$ & $\begin{array}{l}\text { PEPCK origin } \\
\text { (cytosolic/total } \\
\text { activity) }\end{array}$ \\
\hline Digestive gland & 12 & $0.38 \pm 0.08^{b}$ & $4.7 \pm 0.8^{b}$ & $1.03 \pm 0.20^{b}$ & $0.28 \pm 0.01^{c}$ & $92 \%$ \\
\hline Gill & 12 & $0.16 \pm 0.02^{c}$ & $0.3 \pm 0.1^{c}$ & $1.21 \pm 0.20^{b}$ & $0.04 \pm 0.01^{d}$ & $96 \%$ \\
\hline Gonad & 12 & $0.51 \pm 0.17^{b}$ & $3.2 \pm 1.1^{b}$ & $0.99 \pm 0.20^{b}$ & $1.09 \pm 0.20^{b}$ & nd \\
\hline Mantle & 12 & $0.21 \pm 0.04^{c}$ & $0.3 \pm 0.1^{c}$ & $0.97 \pm 0.17^{b}$ & $0.04 \pm 0.01^{d}$ & $99 \%$ \\
\hline Muscle & 12 & $1.51 \pm 0.43^{a}$ & $10.9 \pm 2.5^{\mathrm{a}}$ & $6.10 \pm 1.10^{\mathrm{a}}$ & $2.73 \pm 0.14^{a}$ & $94 \%$ \\
\hline
\end{tabular}

Within each column, homogenous groups are marked with the same alphabetic letters.

nd : non determined

Table 2: Kinetic properties of PK from adductor muscle of C. gigas in normoxia and hypoxia.

\begin{tabular}{lcc}
\hline & normoxia & hypoxia \\
\hline S $_{0.5}$ PEP mM & $0.19 \pm 0.02$ & $1.14 \pm 0.14^{\mathrm{a}}$ \\
I 50 L-alanine mM & $9.30 \pm 1.35$ & $1.36 \pm 0.26^{\mathrm{a}}$ \\
\hline
\end{tabular}

The results are given as means $\pm S E(n=20)$. All parameters were determined at $2 \mathrm{mM}$ ADP. $I_{50} \mathrm{~L}$-alanine was determined at $5 \mathrm{mM}$ PEP.

${ }^{a}$ significantly different from normoxic control 